\title{
ANALISIS KESENJANGAN KUALITAS PELAYANAN TERHADAP KEPUASAN MAHASISWA FAKULTAS HUKUM UNIVERSITAS KATOLIK SANTO THOMAS NEDAN
}

\author{
Oleh: \\ Nawary Saragih, SE, M.Si
}

\begin{abstract}
The purpose of this study was conducted to determine the effect of service quality on student satisfaction Faculty of Law of the Catholic University of Santo Thomas Medan. The sampling technique used is sampling method with a sampling error where sampling based on certain criteria that active students by year of entry proportionally. The data collection is done by using questionnaire data of closed and open (sharpness analysis). Hypothesis analysis is done by using multiple regression analysis and gap analysis.

Obtained multiple linear regression equation $Y=-6,107 X 10,229 X 2-4,202 X 3+++$ 4,317X5 0,503X4. This means that the quality of service (responsiveness, empathy and tangible) positive effect on student satisfaction. While the reliability of service quality assurance, a negative effect on satisfaction Faculty of Law of the Catholic University of Santo Thomas Medan. Interval kesenjanagan Student dissatisfaction is in the interval -337 up to 267 to satisfaction of students, it is necessary to repair the reability (accuracy, speed of service, timeliness in and out perkukliahan. Kesuaian service with the promise offered) and assurance (Alertness Employees in serving the student affairs, Alertness Lecturer in serving the student affairs).
\end{abstract}

In terms of reliability assurance negative influence on satisfaction of students and gap interval in the interval -337 up to 267 to satisfaction of students, efforts are needed improvement to reability and assurance in the hope to close the gap between perceived to increase student satisfaction

Keywords: Quality of service (reliability, responsiveness, assurance, empathy and tangible) satisfaction.

\section{PENDAHULUAN}

Kondisi globalisasi membawa dampak yang besar kepada seluruh bidang pembangunan termasuk dibidang pendidikan. Kondisi ini menuntut para pengelola lembaga pendidikan semakin profesionalisme untuk menciptakan keunggulan kompetitif agar dapat bersaing dalam iklim dan cara yang wajar sehingga tidak merugikan lembaga pendidikan yang bersangkutan, pemerintah dan masyarakat. Karena dalam kenyataan masih banyak kondisi mutu perguruan tinggi di Indonesia belum seperti yang diharapkan sebagai perannya dalam upaya meningkatkan kualitas sumber daya manusia Indonesia melalui pendidikan tinggi.

Universitas Katolik Santo Thomas Medan sebagai salah satu lembaga pendidikan tinggi yang ada di Sumatera Utara diharapkan dapat memberikan pelayanan yang terbaik sesuai dengan kebutuhan dan harapan mahasiswanya. Dengan memberikan pelayanan yang berkualitas maka diharapkan tercipta kepuasan bagi para mahasiswa. Apabila mahasiswa merasa puas terhadap pelayanan yang diberikan maka akan tercipta loyalitas mahasiswa. Namun dalam upaya menciptakan kepuasan mahasiswa di Fakultas Hukum dalam penelitian pendahuluan masih terdapat beberapa permasalahan yang seringkali terjadi yang dapat menimbulkan ketidakpuasan bagi para mahasiswa dalam; aspek pelayanan administrasi akademik oleh Pegawai maupun Dosen belum sesuai dengan harapan, terbatasnya dan tidak 
berfungsinya sarana dan prasarana penunjang pendidikan $(A C, L C D$, kebersihan ruangan kuliah, toilet)

Kondisi sistem manajemen Perguruan Tinggi di Indonesia dewasa ini juga belumlah sepenuhnya memenuhi persyaratan seperti yang diharapkan.Oleh sebab itu dirasa perlu untuk mengadakan perubahan-perubahan, penyempurnaan program kerja dan pelayanan yang lebih mantap, yang disesuaikan dengan tuntutan perkembangan waktu.

Berdasarkan dari perspektif yang demikian kompleksnya, maka Universitas Katolik Santo Thomas Medan yang merupakan salah satu Perguruan Tinggi Swasta di Sumatera Utara harus berupaya memberikan pelayanan jasa pendidikan tinggi yang optimal kepada masyarakat (civitas akademika). Untuk itu pihak manajemen Perguruan Tinggi Universitas Katolik Santo Thomas Medan harus tanggap terhadap perubahan lingkungan internal dan eksternalnya. Dalam hal ini objek yang ingin diteliti adalah Mahasiswa Fakultas Hukum Universitas Katolik Santo Thomas Medan dengan melihat perkembangan jumlah Mahasiswanya seperti pada tabel 1 berikut:

Tabel 1: Jumlah Mahasiswa Fakultas Hukum Unika Santo Thomas Medan Tahun 2010-2015

\begin{tabular}{|c|c|c|c|c|c|c|}
\hline No & 2010 & 2011 & 2012 & 2013 & 2014 & 2015 \\
\hline Jumlah & 465 & 582 & 475 & 444 & 554 & 400 \\
\hline
\end{tabular}

Sumber: BAAK Unika Santo Thomas Medan 2015

Berdasarkan data pada tabel di atas, jumlah mahasiswa Fakultas Hukum Unika Santo Thomas Medan dari tahun 2010-2015 terjadi fluktuasi. Mengapa hal ini terjadi, maka penulis tertarik melakukan penelitian dengan judul: Analisis Kualitas Pelayanan Terhadap Kepuasan Mahasiswa Unika Santo Thomas Medan

\section{Pengertian Pemasaran}

\section{TINJAUAN PUSTAKA}

Pemasaran merupakan salah satu fungsi dari perusahaaan di samping fungsi lainnyaseperti keuangan, produksi dan personalia.Untuk mengetahui lebih jelas tentang pengertianpemasaran, maka penulis mencoba melakukan pendekatan terhadap berbagai rumusanpemasaran yang dikemukakan oleh ahli pemasaran seperti yang dikutip di bawah ini. Pengertian pemasaran menurut Kotler dan Armstrong (1997:6) “Pemasaran adalah suatu proses sosial dan manajerial yang didalamnya individu dankelompok mendapatkan apa yang mereka butuhkan dan inginkan dengan menciptakan,menawarkan dan menukarkan produk/ jasa yang bernilai dengan pihak lain."

Dari definisi diatas dapat diterangkan bahwa arti pemasaran adalah jauh lebih luas daripada arti penjualan. Pemasaran mencakup usaha perusahaan yang dimulai dengan mengidentifikasi kebutuhan konsumen yang perlu dipuaskan, menentukan produk yang hendak diproduksi, menentukan harga produk yang sesuai, menentukan cara-cara promosidan penyaluran atau penjualan produk tersebut.

\section{Pengertian Kualitas Pelayanan}

Kualitas pelayanan dapat didefenisikan sebagai seberapa jauh perbedaan antara kenyataan dan harapan para pelanggan atas layanan yang mereka terima. Kualitas pelayanan dapat diketahui dengan cara membandingkan persepsi para pelanggan atas layanan yang benar-benar mereka terima. Menurut Lewis dan Booms dalam Tjiptono \& Chandra (2005:122), kualitas layanan sebagai ukuran seberapa baik tingkat layanan yang diberikan mampu sesuai dengan harapan pelanggan.Sedangkan menurut Tjiptono (2005:111), kualitas pelayanan adalah 
tingkat keunggulan yang diharapkan dan pengendalian atas tingkat keunggulan tersebut untuk memenuhi keinginan pelanggan.

Menurut Zeithmal dan Bitner (2000:108), ada dua hal kualitas layanan yang ditentukanoleh persepsi konsumen yakni sebagai berikut:

a. Persepsi kualitas pelayanan dalam arti teknis (technical outcome) yang diberikan olehpenyedia jasa.

b. Kualitas dalam arti hasil suatu proses jasa (outcome process) yang diwujudkan dalambentuk bagaimana jasa tersebut diberikan

Berdasarkan pendapat di atas dapat di simpulkan bahwa ada faktor utama yang mempengaruhi kualitas pelayanan yaitu: jasa yang diharapkan dan jasa yang dirasakan/ dipersepsikan. Jika jasa yang rasakan sesuai dengan jasa yang diharapkan maka kualitas pelayanan tersebut dipersepsikan baik/positif.Jika jasa yang dipersepsikan melebihi jasa yang diharapkan, maka kualitas jasa dipersepsikan jasa yang ideal. Dan sebaliknya, apabila jasa yang dipersepsikan lebih buruk dibandingkan jasa yang harapkan, maka jasa di persepsikan buruk/negative.

\section{Karakteristik Jasa}

Menurut Kotler (2008:660) Jasa memiliki empat karakteristik utama yangmembedakan dari suatu barang, yaitu:

a. Intangibility (Tidak Berwujud)

Jasa adalah suatu perbuatan, kinerja (performance).Atau usaha yang hanya bias dikonsumsitetapi tidak bisa dimiliki.Jasa bersifat intangible maksudnya tidak dapatdilihat, dirasa, dicium, didengar atau diraba sebelum dibeli dan dikonsumsi.Dengandemikian, seseorang tidak dapat menilai kualitas dari jasa sebelum merasakan/mengkonsumsi sendiri.

b. Inseparability (Tidak dapat dipisahkan)

Barang biasanya diproduksi, kemudian dijual lalu dikonsumsi.Sedangkan jasaumumnya dijual terlebih dahulu, baru kemudian diproduksi dan dikonsumsi secarabersamaan.Interaksi antara penyedia jasa dan pelanggan merupakan ciri khusus dalampemasaran jasa.Dalam hubungan penyedia jasa dan pelanggan ini, efektivitas individuyang menyampaikan jasa (contact-personnel) merupakan unsur penting.

c. Variability (Keanekarupaan)

Jasa bersifat sangat variabel karena merupakan non-standarized output, artinyabanyak variasi bentuk, kualitas, dan jenis, tergantung pada siapa, kapan, dan dimana jasatersebut dihasilkan. Para pembeli jasa sangat peduli dengan variabilitas yang tinggi ini danseringkali mereka meminta pendapat orang lain sebelum memutuskan untuk memilih.

d. Perishability (Tidak tahan lama)

Jasa merupakan komoditas tidak tahan lama dan tidak dapat disimpan.Hal ini tidakmenjadi masalah bila permintaannya tetap karena mudah untuk menyiapkan pelayananuntuk permintaan tersebut sebelumnya.Bila permintaan berfluktuasi, berbagaipermasalahan muncul berkaitan dengan kapasitas menganggur (saat permintaan sepi) danpelanggan tidak terlayani dengan resiko mereka kecewa atau beralih ke penyedia jasalainnya (saat permintaan puncak).

\section{Gap (Kesenjangan) Kualitas Pelayanan}

Suatu cara perusahaan jasa untuk tetap dapat unggul bersaing adalah memberi jasa dengan kualitas yang lebih tinggi dari pesaing secara konsisten. Untuk mengetahui harapan pelanggan maka perusahaan itu dibentuk dari pengalaman masa lalu, dari pembicaraan mulut 
ke mulut serta promosi yang dilakukan oleh perusahaan tersebut, dan kemudian dibandingkan.

Parasuraman, Zeinthami, dan Berry $(2001 ; 105)$ merumuskan sebuah model mutu jasa yang menggaris bawahi ketentuan penting yang perlu diketahui oleh pemberi jasa supaya bisa melayani jasa sesuai dengan pengharapan konsumen. Model ini mengidentifikasikan lima kesenjangan yang menyebabkan gagalnya pelayanan jasa.

Kelima kesenjangan itu diuraikan sebagai berikut :

a. Kesenjangan pengharapan konsumen dengan persepsi manajemen. Manajemen tidak selalu memahami dengan tepat apa yang diinginkan konsumen atau bagaimana konsumen menilai masing-masing komponen jasa itu.

b. Kesenjangan persepsi manajemen dengan spesifikasi mutu jasa. Manajemen barangkali belum menetapkan standart mutu yang sangat jelas, atau barangkali manajemen telah menetapkan standart mutu yang sangat jelas tapi tidak realistis, atau barangkali standart mutu ini jelas dan realistis, tetapi manajemen tidak memiliki komitmen kuat untuk mewujudkan peringkat seperti itu.

c. Kesenjangan spesifikasi mutu jasa dengan pemberian jasa. Ada banyak faktor yang mempengaruhi pemberian jasa.

d. Kesenjangan penyerahan jasa dengan komunikasi eksternal. Pengharapan konsumen dipengaruhi oleh pemberi jasa melalui komunikasi.

e. Kesenjangan jasa yang dimilki konsumen dengan jasa yang diharapkan konsumen. Kesenjangan ini timbul bila satu atau lebih dari kesenjangan-kesenjangan yang telah disebutkan terjadi. Menjadi jelaslah mengapapemberi jasa mengalami kesulitan dalam upaya mereka meyerahkan mutu jasa sesuai dengan pengharapan konsumen.

Parasuraman dan kawan-kawan telah menemukan dimensi kualitas jasa yang dapat dirangkum menjadi lima dimensi pokok, meliputi :

a. Tangibels, atau bukti fisik yaitu kemampuan suatu perusahaan dalam menunjukkan eksistensinya kepada pihak eksternal. Penampilan dan kemampuan sarana danprasarana fisik perusahaan dan keadaan lingkungan sekitarnya adalah bukti nyata daripelayanan yang diberikan oleh pemberi jasa.

b. Reliability, atau kehandalan yaitu kemampuan perusahaan untuk memberikan pelayanan sesuai yang dijanjikan secara akurat dan terpercaya.

c. Daya tanggap (Responsiveness), yaitu keinginan para staf untuk membantu para pelanggan dan memberikan pelayanan dengan tanggap.

d. Jaminan (Assurance), mencakup pengetahuan, kemampuan, kesopanan, dan sifat dapt dipercaya yang dimiliki para staff, bebas dari bahaya, resiko atau keragu-raguan.

e. Empati (emphaty), meliputi kemudahan dalam melakukan hubungan, komunikasi yang baik, perhatian pribadi, dan memahami kebutuhan para pelanggan.

Berbagai hasil studi menunjukkan bahwa perusahaan jasa yang dikelola sangat baik memiliki sejumlah persamaan, diantaranya adalah :

a. Konsep strategi: Perusahaan jasa ternama memiliki pengertian yang jelas mengenai pelanggan sasaran dan kebutuhan pelanggan yang akan mereka puaskan. Untuk itu dikembangkan strategi khusus untuk memuaskan kebutuhan ini yang menghasilkan kesetiaan pelanggan.

b. Sejarah komitmen kualitas manajemen puncak: Tidak hanya melihat pada prestasi keuangan bulanan, melainkan juga pada kinerja jasa.

c. Penetapan standart tinggi: Penyediaan jasa terbaik menetapkan standart kualitas yang tinggi, antara lain berupa kecepatan respon terhadap keluhan pelanggan, ketepatan. 
d. Sistem untuk memonitor kinerja jasa: Menanggapi keluhan pelanggan dengan cepat dan ramah.

e. Sistem untuk memuaskan keluhan pelanggan: Menanggapi keluhan pelanggan dengan cepat dan ramah.

f. Memuaskan karyawan sama dengan pelanggan: Manajemen menjalankan pemasaran internal dan menciptakan lingkungan yang mendukung dan menghargai prestasi layanan pelanggan yang baik secara teratur, manajemen memeriksa kepuasan pelanggan.

\section{Pengertian Kepuasan Konsumen}

Menurut Supranto (2001:233) Kepuasan adalah: Tingkat perasaan seseorang setelah membandingkan kinerja/hasil yang dirasakannya. Jadi, tingkat kepuasan konsumen akan terpenuhi bila mereka memperoleh apa yang mereka inginkan, pada saat mereka membutuhkan ditempat yang mereka inginkan dan dengan cara yang ditentukan.

Terdapat beberapa cara untuk menarik dan mempertahankan pelanggan antara lain adalah :

a. Memberikan pelayanan yang lebih baik daripada pesaing, sehingga pelanggan merasa puas dan tidak beralih ke lembaga lain.

b. Memberikan harga yang konstan dengan pelayanan yang memuaskan. Pelanggan yang didasarkan pada hubungan dengan pelanggan dan mencakup pemberian keuntungan financial serta sosial disamping ikatan struktural dengan pelanggan.

\section{METODOLOGI PENELITIAN}

\section{Ruang Lingkup Penelitian}

Metode penelitian adalah salah satu cara yang sifatnya sistematik dan objektif dengan tujuan untuk memperoleh, mengumpulkan informasi atau data-data yang diteliti secara efisien, yang dapat digunakan sebagai pedoman dalam melaksanakan penelitian. Metode penelitian ini meliputi : populasi dan sampel, operasional variabel, teknik pengumpulan data, teknik analisis dan hipotesis.

\section{Metode Penarikan Sampel}

Populasi dalam penelitian ini adalah seluruh Mahasiswa Fakultas Hukum Unika Santo Thomas Medan. Sampel adalah bagian dari populasi. Penentuan sampel dilakukan secara insidental yaitu kuesioner diberikan pada Mahasiswa yang bertemu dengan peneliti pada saat penelitian dilakukan di lokasi penelitian. Sampel penelitian ditentukan berdasarkan kesalahan (samplingerror) maksimum yang diinginkan, dengan rumus (Supranto, 2009:113), maka jumlah sampel yang dibutuhkan $(n)=96,04$ dibulatkan menjadi 96 orang.

\section{Operasionalisasi Variabel} berikut:

Defenisi operasionalisasi dari masing-masing variabel yang akan diteliti sebagai

1. Reliability (X1) yaitu kemampuan organisasi untuk memberikan pelayanan sesuai yang dijanjikan secara akurat dan terpercaya. Dengan indikator: Ketepatan dan kecepatan pelayanan pegawai, Ketepatan masuk dan keluar perkukliahan . Kesuaian layanan dengan janji yang ditawarkan oleh Pegawai. Kesuaian layanan dengan janji yang ditawarkan.

2. Responsiveness $\mathrm{X} 2$ ) yaitu suatu kemauan untuk membantu dan memberikan pelayanan yang cepat dan tepat kepada pelanggan/ Mahasiswa, dengan penyampaian informasi yang 
jelas. Dengan indikator: Kesigapan Pegawai dalam melayani urusan Mahasiswa, Kesigapan Dosen dalam melayani urusan Mahasiswa.

3. Assurance (X3) yaitu pengetahuan, kesopansantunan, dan kemampuan para pegawai untuk menumbuhkan rasa percaya para pelanggan. Dengan indikator: Kesigapan Pegawai dalam melayani urusan Mahasiswa, Kesigapan Dosen dalam melayani urusan Mahasiswa.

4. Empathy (X4) yaitu memberikan perhatian yang tulus dan bersifat individual atau pribadi yang diberikan kepada para pelanggan/ Mahasiswa dengan berupaya memahami keinginan konsumen. Dengan indikator: Kemudahan menghubungi Pegawai, Kemudahan menghubungi Dosen, Kemampuan Pegawai berkomunikasi dengan Mahasiswa, Kemampuan Dosen berkomunikasi dengan Mahasiswa, Kemampuan Dosen mengajar Dikelas.

5. Tangible (X5) yaitu kemampuan suatu organisasi dalam menunjukkan eksistensinya kepada pihak eksternal. Penampilan dan kemampuan sarana dan prasarana fisik organisasi dan keadaan lingkugan sekitarnya adalah buktinyata dari pelayanan yang diberikan oleh pemberi jasa. Dengan indikator: Penampilan fisik gedung. Tempat parkir. Kebersihan ruangan. Kebersihan Toilet. Kenyamanan kampus. Kenyamanan kelas. Penampilan Dosen. Penampilan Pegawai. Kursi kuliah. Penerangan ruangan kuliah. White board.. LCD. Kipas angin. AC ruangan. Kecepatan informasi melalui papan pengumuman di Fakultas Hukum.

6. Kepuasan Mahasiswa (Y) yaitu Tingkat perasaan se- seorang setelah mem-bandingkan kinerja yang dirasakannya, yang indikatornya sama variabel $\mathrm{x}$.

\section{Teknik Pengumpulan Data}

Teknik pengumpulan data yang digunakan adalah kuesioner. Kuesioner dilakukan dengan membagikan angket kepada Mahasisawa sebagai responden di Fakultas Hukum Unika Santo Thomas Medan. Daftar kuesioner dibuat dalam bentuk pertanyaan tertutup dengan mencantumkan beberapa pilihan jawaban dan responden memilih salah satu jawaban yang paling tepat dan pertanyaan terbuka untuk menambah ketajaman análisis dalam pembahas sebagai untuk saran yang tidak terkaper oleh peneliti. Setelah daftar kuesioner diisi, kemudian dikumpulkan kembali untuk dianalisis lebih lanjut.

\section{Metode Analisis}

\section{a. Uji Validitas}

Uji validitas berguna untuk menguji ketepatan hasil kuesioner. Dalam hal ini teknik korelasi untuk menentukan validitas item ini sampai sekarang merupakan teknik yang paling banyak digunakan. Selanjutnya dalam memberikan interprestasi terhadap koefisien korelasi, dimana item yang mempunyai korelasi positif dengan kriteria (skor total) serta korelasi yang tinggi pula.

Menurut Sugiyono (2008:114)."jumlah anggota sampel digunakan sekitar 30 orang". Biasanya, syarat minimum yang dianggap memenuhi syarat adalah kalau $r=0,3$. Jadi, jika korelasi antara butir dengan skor total kurang dari 0,3, maka butir dalam instrumen tersebut dinyatakan tidak valid. Untuk menghitung koefisien korelasi digunakan Corrected Item-Total Correlation.

\section{b. Uji Reliabilitas}


Uji reliabilitas adalah menguji konsistensi jawaban responden apabila kuesioner tersebut dibagikan secara berulang-ulang. Secara internal realibilitas instrumen dapat diuji dengan menganalisis konsistensi butir-butir yang ada pada instrumen dengan teknik tertentu.

Menurut Sugiyono (2008:122), "pengujian reliabilitas dengan internal consistency, dilakukan dengan cara mencoba instrumen sekali saja, kemudian data yang diperoleh dianalisis dengan teknik tertentu". Hasil analisis dapat digunakan untuk memprediksi reliabilitas instrumen. Pengujian realibilitas instrumen dapat Cronbach's Alpha if Item Deleted. Pada pengujian ini dinilai reliabel jika reliabilitas hitung lebih besar dari 0,50 di mana kriteria sebagai berikut: jika $\alpha>0,50$ artinya instrumen reliabel, dan jika $\alpha<0,50$ artinya instrumen tidak reliabel

\section{c. Analisis Regresi Linear Berganda}

Analisis ini dimaksudkan untuk mengetahui besarnya pengaruh kualitas pelayanan terhadap kepuasan Mahasiswa Fakultas Hukum Unika Santo Thomas Medan dengan menggunakan rumus regresi linear berganda seperti yang dikutip dari J. Supranto (2009:239): $Y=b_{0}+b_{1} X_{1}+b_{2} X_{2}+b_{3} X_{3}+b_{4} X_{4}+b_{5} X_{5}+\varepsilon$

Keterangan: Rumus ini diaplikasi dalam penelitian ini sebagai berikut:

Y: Kepuasan Mahasiswa, X1: Reliability (kehandalan), X2:Responsiveness (ketanggapan),X3 :Assurance (jaminan), X4:Empathy (empati), X5:Tangible (bukti fisik), bo:Konstanta, b:Koefisien regresi, $\varepsilon$ : Tingkat kesalahan estimasi

\section{HASIL PENELITIAN DAN PEMBAHASAN}

\section{Hasil Penelitian}

a. Uji Validitas dan Uji Reabilitas

Hasil pengujian terhadap validitas dan reabilitas menunjukkan bahwa indikator kualitas pelayanan dan kepuasan Mahasiswa pada Fakultas Hukum Universitas Katolik Santo Thomas Medan sudah valid dan reabel, karena nilai korelasi hitung semua di atas 0,30 dan nilai Alpha Cronbach's lebih besar dari 0,50

b. Pengujian Hipotesis

Berdasarkan hasil analisis regresi berganda dengan olah data menggunakan MS SPSS versi 20.0 di dapatkan hasil seperti pada tabel 2 berikut:

\begin{tabular}{|c|c|c|c|c|c|c|c|c|c|}
\hline \multicolumn{10}{|c|}{ Model Summary } \\
\hline \multirow[b]{2}{*}{ Model } & \multirow[b]{2}{*}{$\mathrm{R}$} & \multirow[b]{2}{*}{ R Square } & \multirow[b]{2}{*}{$\begin{array}{l}\text { Adjusted R } \\
\text { Square }\end{array}$} & \multirow[b]{2}{*}{$\begin{array}{l}\text { Std. Error of } \\
\text { the Estimate }\end{array}$} & \multicolumn{5}{|c|}{ Change Statistics } \\
\hline & & & & & $\begin{array}{l}\text { R Square } \\
\text { Change }\end{array}$ & F Change & df1 & df2 & Sig. F Change \\
\hline 1 & $.758^{\mathrm{a}}$ & .575 & .551 & 13.790 & .575 & 24.319 & 5 & 90 & .000 \\
\hline
\end{tabular}

a. Predictors: (Constant), $\times 5, \times 1, \times 3, \times 4, \times 2$

\begin{tabular}{|c|c|c|c|c|c|c|}
\hline \multicolumn{7}{|c|}{ ANOVA } \\
\hline Model & & $\begin{array}{l}\text { Sum of } \\
\text { Squares }\end{array}$ & df & Mean Square & $\mathrm{F}$ & Sig. \\
\hline 1 & $\begin{array}{l}\text { Regression } \\
\text { Residual } \\
\text { Total }\end{array}$ & $\begin{array}{l}23121.719 \\
17113.771 \\
40235.490\end{array}$ & $\begin{array}{r}5 \\
90 \\
95\end{array}$ & $\begin{array}{r}4624.344 \\
190.153\end{array}$ & 24.319 & $.000^{a}$ \\
\hline
\end{tabular}

a. Predictors: (Constant), $\times 5, \times 1, \times 3, \times 4, \times 2$

b. Dependent Variable: $y$

\begin{tabular}{|c|c|c|c|c|c|c|}
\hline \multicolumn{7}{|c|}{ Coefficients ${ }^{a}$} \\
\hline \multirow{2}{*}{\multicolumn{2}{|c|}{ Madel }} & \multicolumn{2}{|c|}{ Unstandardized coefficients } & \multirow{2}{*}{$\begin{array}{c}\text { Standardized } \\
\text { Coefficients } \\
\text { Beta }\end{array}$} & \multirow[b]{2}{*}{$\mathbf{t}$} & \multirow[b]{2}{*}{ Sig. } \\
\hline & & $\mathrm{B}$ & Std. Error & & & \\
\hline \multirow[t]{6}{*}{1} & (Constant) & 3.742 & 21.963 & & .170 & .865 \\
\hline & $\times 1$ & -8.010 & 1.311 & -.665 & -6.107 & .000 \\
\hline & $\times 2$ & 1.338 & 5.841 & .064 & .229 & .819 \\
\hline & $\times 3$ & -5.468 & 1.301 & -.544 & -4.202 & .000 \\
\hline & $\times 4$ & .938 & 1.866 & .106 & .503 & .616 \\
\hline & $\times 5$ & 4.896 & 1.134 & 1.357 & 4.317 & .000 \\
\hline
\end{tabular}


Persamaan regresi linear berganda diperoleh $Y=3,742-8,010 \times 1+1,338 X 2-$

$5,468 X 3+0,938 \times 4+4,896 \times 5$. Artinya kualitas pelayanan (responsiveness, emphaty dan tangible) berpengaruh positif terhadap kepuasan Mahasiswa Fakultas Hukum Universitas Katolik Santo Thomas Medan. Sedangkan reliability assurance, berpengaruh negative terhadap kepuasan Mahasiswa Fakultas Hukum Universitas Katolik Santo Thomas Medan.

Untuk analisis kesenjanagan disajikan data antara harapan dengan yang dirasakan sebagai berikut:

Tabel: 3 Data Harapan dengan yang dirasakan

\begin{tabular}{|c|c|c|c|c|}
\hline No & Dimensi & Harapan & Yang dirasakan & Gap \\
\hline 1 & \multirow{4}{*}{ Keandalan(Reability) } & 391 & 217 & -174 \\
\hline 2 & & 208 & 334 & 126 \\
\hline 3 & & 381 & 190 & -191 \\
\hline 4 & & 263 & 148 & -115 \\
\hline 1 & \multirow[b]{2}{*}{ Kesigapan(Responsiveness) } & 437 & 255 & -182 \\
\hline 2 & & 437 & 277 & -160 \\
\hline 1 & \multirow{5}{*}{ Jaminan (Assurance) } & 420 & 270 & -150 \\
\hline 2 & & 424 & 319 & -105 \\
\hline 3 & & 449 & 322 & -127 \\
\hline 4 & & 451 & 366 & -85 \\
\hline 5 & & 467 & 366 & -101 \\
\hline 1 & \multirow{5}{*}{ Empati (Empathy) } & 434 & 311 & -123 \\
\hline 2 & & 436 & 347 & -89 \\
\hline 3 & & 431 & 302 & -129 \\
\hline 4 & & 437 & 348 & -89 \\
\hline 5 & & 452 & 368 & -84 \\
\hline 1 & \multirow{15}{*}{ Realitas (Tangbles) } & 436 & 319 & -117 \\
\hline 2 & & 437 & 216 & -221 \\
\hline 3 & & 437 & 349 & -88 \\
\hline 4 & & 434 & 231 & -203 \\
\hline 5 & & 438 & 361 & -77 \\
\hline 6 & & 436 & 357 & -79 \\
\hline 7 & & 438 & 359 & -79 \\
\hline 8 & & 436 & 301 & -135 \\
\hline 9 & & 436 & 216 & -220 \\
\hline 10 & & 436 & 275 & -161 \\
\hline 11 & & 448 & 244 & -204 \\
\hline 12 & & 461 & 126 & -335 \\
\hline 13 & & 458 & 235 & -223 \\
\hline 14 & & 459 & 122 & -337 \\
\hline 15 & & 395 & 128 & -267 \\
\hline
\end{tabular}


Berdasarkan data di atas, diolah untuk disajikan dalam grafik untuk analisis kesenjangan lebih lanjut sebagai berikut:

Gambar 1: Grafik Analisis Kesenjangan

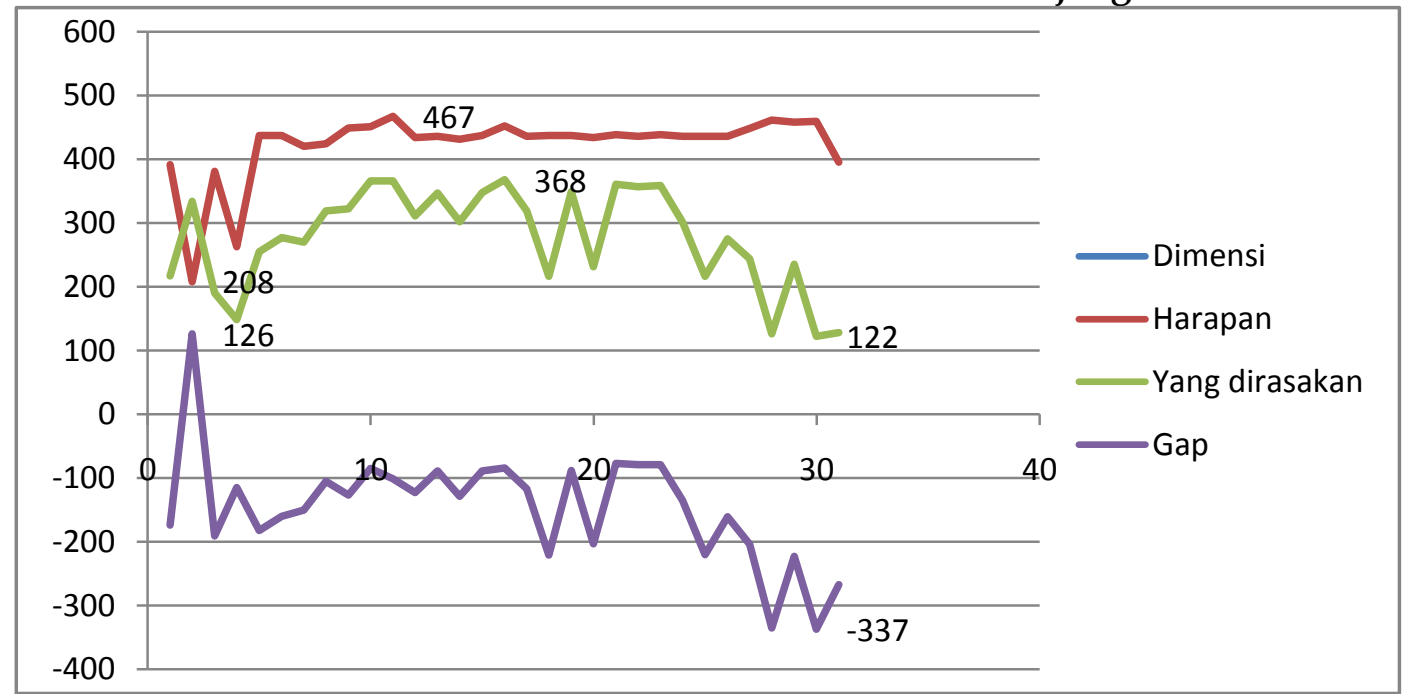

Grafik di atas menunjukkan bahwa kualitas pelayanan harapan Mahasiswa berada pada interval 208 sampai dengan 467. Sedangkan kualitas pelayanan yang dirasakan berada pada interval 122 sampai dengan 368. Dan kesenjangan kualitas pelayanan antara harapan dengan yang dirasakan berada pada interval -337 sampai dengan 126 artinya ada kesenjangan ketidakpuasan kualitas pelayanan antara harapan dengan yang dirasakan oleh Mahasiswa Fakultas Hukum Universitas Katolik Santo Thomas Medan.

Karena adanya gap berada pada interval -337 sampai dengan 267 terhadap kepuasan Mahasiswa, maka diperlukan perbaikan terhadap reability dan assurance dalam mendekatkan jarak antara harapan dengan yang dirasakan untuk meningkatkan kepuasan Mahasiswa.

\section{Pembahasan}

Nilai koefisien korelasi (R) sebesar 0,058, artinya kualitas pelayanan mempunyai hubungan kuat terhadap kepuasan Mahasiswa Fakultas Hukum Universitas Katolik Santo Thomas Medan. Nilai koefisien determinasi ( $R$ Square) sebesar 0,575, artinya kepuasan Mahasiswa Fakultas Hukum Universitas Katolik Santo Thomas Medan dapat dijelaskan oleh kualitas pelayanan sebesar 57,5 \%, sedangkan 42,5\% lagi dijelaskan faktor lain.

\section{Kesimpulan}

\section{KESIMPULAN DAN SARAN}

Kualitas pelayanan (responsiveness, emphaty dan tangible) berpengaruh positif terhadap kepuasan Mahasiswa Fakultas Hukum Universitas Katolik Santo Thomas Medan. Sedangkan kualitas pelayanan reliability assurance, berpengaruh negative terhadap kepuasan Mahasiswa Fakultas Hukum Universitas Katolik Santo Thomas Medan.

Interval kesenjanagan ketidakpuasan Mahasiswa berada pada interval -337 sampai dengan 267 terhadap kepuasan Mahasiswa, maka diperlukan perbaikan terhadap reability (ketepatan,kecepatan pelayanan, ketepatan waktu masuk dan keluar perkukliahan. Kesuaian layanan dengan janji yang ditawarkan) dan assurance (Kesigapan Pegawai dalam melayani urusan Mahasiswa, Kesigapan Dosen dalam melayani urusan Mahasiswa) dalam upaya 
mendekatkan jarak antara harapan dengan yang dirasakan untuk meningkatkan kepuasan Mahasiswa.

Saran

Dilihat dari sisi pengaruh reliability assurance negatif terhadap kepuasan Mahasiswa maupun dari interval gap pada interval -337 sampai dengan 267 terhadap kepuasan Mahasiswa, maka diperlukan perbaikan terhadap reability dan assurance dalam mendekatkan jarak antara harapan dengan yang dirasakan untuk meningkatkan kepuasan Mahasiswa.

\section{DAFTAR PUSTAKA}

Kotler dan Armstrong, 1997, Dasar-Dasar Pemasaran: Principles of Marketing7e Jilid 1.Alih bahasa oleh Alexander Sindoro, Prenhalindo. Jakarta.

Kotler, Philip, 2008, Alih Bahasa: Benyamin Molan; Penyunting: Bambang Sarwiji, SE;Manajemen Pemasaran, edisi 12 Jilid 2; PT. INDEKS, Jakarta.

Sugiyono, 2008.Metode Penelitian Bisnis, Cetakan Keenam, Bandung: Alfabeta.

Supranto, J. 2009. Statistik Teori dan Aplikasi. Jilid 2, Edisi Ketujuh, Jakarta: Erlangga.

Tjiptono, Fandy dan Chandra, Gregorius, 2005, Service, Quality and Satisfaction, PenerbitAndi. Yogyakarta

Zeithmal dan Bitner, 2000, Service Marketing, Irwin Mc Graw - Hill, Boston. 